International Journal of Business Management, Entrepreneurship and Innovation, Volume 3, Issue 1, 2021, PP 65-77, ISSN 2707-8027

[IJCAB

\title{
Total Quality Management Practices and Performance of Deposit Taking Savings and Credit Cooperatives in Mombasa County, Kenya
}

\author{
Gladys Kadzo Menza ${ }^{1}$, James M. Rugami² \\ ${ }^{1}$ Department of Business Administration, School of Business, Kenyatta University, Kenya \\ ${ }^{2}$ Lecturer, Department of Business Administration, School of Business, Kenyatta University, \\ Kenya
}

\begin{abstract}
Savings and credit cooperatives are a crucial part of Kenya's financial system. Compared to commercial banks, this is smaller but its significance is far much greater. Despite their important contribution towards the growth of the economy, many challenges are faced by the Saccos. Key among the drawbacks facing Savings and credit cooperatives is increased level of competition in the financial sector. The Savings and credit cooperatives to remain driven and focused in achieving their objectives, they have re-strategize their direction. The study sought to how Mombasa County deposit taking Saccos are impacted by TQM practices. Particularly, the study sought to examine how Mombasa deposit taking saccos' performance was affected by Customer focus, employee involvement, supplier partnerships and commitment of top management. Performance was addressed from increased market share and revenue growth point of view. Quality improvement theory, Knowledge-based theory and RBV theories guided the research. A descriptive research design was employed. Board members and top managers of all the thirteen deposit taking Savings and credit cooperatives in Mombasa County were targeted. A census approach was used in identifying and subjecting all the County's operational and registered Saccos. The preferred study respondents were then purposively selected CEOs, Branch managers, Operations Managers, Credit Managers and 4 Executive Board Members. As a result, the total respondents of the study were 104, eight from each deposit taking Sacco. Primary data collection was by questionnaires and secondary data gotten from the Saccos'financial statements and other reports. Analysis was by inferential and descriptive statistics and the primary analytical models were regression and correlation analysis. A wide performance disparity in the Saccos was discovered. It was demonstrated that Mombasa deposit taking saccos' performance was affected by Customer focus, employee involvement, supplier partnerships and commitment of top management. The Determination Coefficient is at 0.785 implying that a variation of $78.5 \%$ in the SACCOs' performance is explained by independent variables' variability; customer focus, employee involvement, supplier partnership and commitment of top management. Pearson Correlation Analysis indicated that all TQM practices variables studied i.e customer focus, employee involvement, supplier partnership and commitment of top management and performance of deposit taking SACCOs positively related. Given that the study focused only on deposit taking saccos in Mombasa county, the results may not apply to all Saccos across Kenya. Therefore, it is recommended that a study is done cutting across all the Saccos in Kenya that would allow for broader generalization of findings. The findings will be beneficial to Managers, academicians, Investors, researchers, and the government as it will inform their decisions regarding the important subject of performance.
\end{abstract}

Key Words: Total Quality Management Practices, Management Commitment, Supplier Partnerships, Employee Involvement, Customer Focus

DOI: 10.35942/jbmed.v3i1.165 
International Journal of Business Management, Entrepreneurship and Innovation, Volume 3, Issue 1, 2021, PP 65-77, ISSN 2707-8027

if JCAB

\section{Cite this Article:}

Menza, G., \& Rugami, J. (2021). Total Quality Management Practices and Performance of Deposit Taking Savings and Credit Cooperatives in Mombasa County, Kenya. International Journal of Business Management, Entrepreneurship, and Innovation, 3(1), 65-77. https://doi.org/10.35942/jbmed.v3i1.165

\section{Introduction}

Delivering quality service in today's environment with competition globally is viewed as a fundamental technique for progress and survival and in turn leads to good performance (Psychogios and Priporas, 2011). Firms endeavor to accomplish amazing operational execution to serve the requirements of the general public in which they exist, through continuous improvement of their products and services. As per Kaynak (2012), global markets are becoming progressively integrated, the pressure of ensuring that service industry's quality performance is current is becoming strong. TQM is an approach of management seeking to achieve organizational longterm success by satisfying customers. By adopting TQM practices, the members within a company takes part in culture, services and processes improvement in the work place. According to World health Organization (2011), TQM is reflecting part of the business Organizations' effective methodologies enhancing their competitive advantage. Organizations have done various investigations on TQM practices, to establish their importance in various sectors such as manufacturing and banking.

In most African nations, the adoption of TQM practices in the private sector seems farfetched. In any case, the selection of this belief system by most companies has been hampered because of inadequate literature on the effect of this philosophy on their execution, prompting their rebelliousness with the sound practices of TQM implementation (Oluwatoyin and Oluseun, 2009). In Kenya, SACCOS have been charged as the soul of cutting-edge economies (Ghobadian and Gallear, 2010) hence they are perceived as the foundation of monetary development. Kenya has more than five thousand SACCOs of which two hundred and fifteen are deposit taking. Even with a few of the deposit taking SACCOs in Mombasa county trying to practice TQM haphazardly, because of their non-compliance with the sound practices of TQM, their efforts have been hampered. This has resulted to challenges like customer focus lack, lack of top management commitment inadequate employee involvement, lack of continuous improvement of processes, lack of ample knowledge on TQM, cultural divide where quality is viewed as a departmental responsibility more than an organization-wide responsibility, lack of resources for TQM implementation and poor change management (Atieno, 2015). These challenges have greatly affected the performance of the deposits taking saccos within Mombasa County thereby resulting to reduction in their profitability, market share and inefficiency of their business processes.

TQM seeks to help organizations in understanding their customers as well as the market. It provides an opportunity for the deposit taking Saccos to manage competition by applying TQM practices. The dynamic economy and the need to maximize resources in development, administration and distribution of consistent low cost products and services, has made deposit taking SACCOs seek ways of improving their planning, designing and implementation of their processes to meet the requirements of their potential targeted clients and lessen the over reliance on stakeholders (Oluwatoyin and Oluseun, 2009). In this context, Oluwatoyin and Oluseun (2009), claim there is need for Organizations to apply TQM practices and continue doing research to establish its accruing benefits to organizational performance, especially in developing economies. 
International Journal of Business Management, Entrepreneurship and Innovation, Volume 3, Issue 1, 2021, PP 65-77, ISSN 2707-8027

iJCAB

A Savings and Credit Cooperative is a financial institution which pools savings for its customers and in return gives them access to credit facilities (SASRA, 2013). Despite operating within an increasingly competitive and technologically sophisticated financial services sector, deposit taking SACCOs continue to show great depth of resilience and stability as evidenced by their doubledigit growth rate in all the key parameters of performance (SASRA, 2019). The total assets increased by $12.41 \%$ to cross the half-trillion mark and reach Kshs 556.71 Billion, while the total deposits increased by $11.27 \%$ to reach Kshs 380.44 Billion in 2019 . The demand for credit facilities from DT-SACCOs continues to grow resulting in the increase of the gross loans by $12.09 \%$ to reach Kshs 419.55 Billion (SASRA, 2019). The Kenya Financial Sector Stability Report, 2018 showed that the DT-SACCOs total assets share of the national nominal GDP was $5.55 \%$ in 2018; and projected that the share of the national nominal GDP would increase to about $5.72 \%$ in 2019 , thereby underscoring the importance of DT-SACCOs in the economy. (SASRA, 2019). Furthermore, Schumpeter (2009) observed that the more efficient the financial sector is, the better the economy and hence wealth maximization of shareholders is achieved. Mombasa has a total of 120 active Cooperative Societies with a total membership of 22, 086, total turnover of 423,563,420 shillings and total share capital and deposit of 35,909,834 and 2,138,192,125 shillings respectively (Njanja and Pelissier, 2010). Many Saccos in Mombasa County have adopted a performance-based approach to help them achieve both their short term and long-term objectives by cutting on costs and increasing their revenues and mission effectiveness (Richard, Devinney, Yip, \& Johnson, 2009).

\section{Statement of the Problem}

According to MOCD\&M (2010), the Kenyan SACCO sector is contributing so much to the economy and the total financial with over $40 \%$ of the GDP of the nation industry. Despite this rapid growth, their full potential exploitation is hindered by many challenges that they face (Muchibo, 2005). Faced by stiff competition from banks and other financial institutions, governance issues, liquidity issues, weak internal processes among other challenges, most deposit taking Saccos in Mombasa County have been struggling to survive, thereby forcing them to embrace TQM practices with the aim of improving performance. Implementing TQM practices can lead to a $90 \%$ improvement rate in customer satisfaction, financial performance, operating procedures and employee relations (Rategan, 2012). Top management is the key dependent factor in order to pursue successful TQM implementation and achieve a product quality that is high. On the contrary, Mahmoun, and Rice (2014) is of the opinion that product quality level achieved and support for quality by top management do not relate. Thus, on how overall performance of business is affected by TQM practices, the reported findings are conflicting. While many studies have been done on TQM practices role on various business organizations performance, not enough focusing on financial sector and in the Sacco sub sector lesser studies have carried out even though its major contribution to the country's economic growth.

Nyaga \& Gakobo (2017) embarked on a study to establish how performance of Saccos in Kirinyaga County, Kenya was effected by quality management practices. It found out that top management commitment and support positively and significantly affected organizational performance. Karani and Bichanga (2012), researched on the effects of TQM practices in service institutions' business performance focusing on KWS. The study found out that in TQM practices implementation in the service industry was positively impacted by effective leadership and top management commitment. The studies present methodological gaps on the necessity of addressing other firm performance facets. Further there are clear contextual gaps on the necessity of financial 
International Journal of Business Management, Entrepreneurship and Innovation, Volume 3, Issue 1, 2021, PP 65-77, ISSN 2707-8027

\section{IIJCAB}

sector being addressed, particularly the Sacco subsector. The studies also present empirical gaps on the need to consider all TQM practices wholesomely. The researcher decided to undertake a research on how Mombasa County deposit taking Saccos are impacted by TQM practices with the aim of contributing to the knowledge growth in the area.

\section{Study Objective}

The general objective was to determine how Mombasa County deposit taking Saccos are impacted by TQM practices.

Specific objectives were:

i. To establish how Mombasa County SACCOs' performance is impacted by top management commitment.

ii. To determine how Mombasa County SACCOs' performance is impacted by supplier partnerships.

iii. To assess Mombasa County SACCOs' performance is impacted by employee involvement.

iv. To find out Mombasa County SACCOs' performance is influenced by customer focus.

\section{Theoretical Review}

\subsection{Resource Based View Theory}

It was proposed by Wernefelt (1984) and is being utilized widely in different business organization context aiming at achieving competitive advantage. The theory emphasizes that improved performance and competitive advantage is as a result of capabilities and resources. New dimensions to understand TQM as a discipline are introduced by the model and differential firm performance knowledge body expanded effectively (Barney and Clark, 2007). Barney, Wright, \& Ketchen (2001) posit that the theory's basic premise is that by delivering superior value to clients innovatively, an organization increases its competitive edge and subsequently improve its performance According to King, (2007), the theory argues that the resources which firms have are critical to their performance. 2 Resources types can be present in an organization as presented by the theorists: intangible and tangible resources. There is no physical presence in intangible resources but a firm can have ownership. These are: intellectual property, trademarks and brand reputation. On the other hand, tangible assets are physical. They are: capital, equipment, machinery, buildings and land. To the firms, tangible resources have little advantage in the long run as they can be equally be obtained from the market by competitor (Newbert, 2008). Intangible assets are the major competitive advantage source since they are unique and are built over a long duration and unlike the physical assets, competitors can never acquire them from the market.

Barney, Wright \& Ketchen (2001) posit that the theory has an assumption that resources ought to be immobile and heterogeneous. It means that for the sources to be sustained competitive advantage sources, capabilities, skills and other assets of an organization should differ across companies and that the assets cannot be moved easily from one organization to the other. This ensures that implementing similar strategies and replicating competitor's resources is difficult. Base on Baney (2011), as described in the RBV framework, Intangible assets qualify as sustained competitive advantage sources. In transforming short-tern competitive advantage to long-term, an organization need the resources to be perfectly immobile and heterogeneous (Newbert, 2008). As such, in guiding this research, the theory was crucial especially on the aspect of top management commitment and employee involvement on performance which is embraced as one of the key objectives of the study. 
International Journal of Business Management, Entrepreneurship and Innovation, Volume 3, Issue 1, 2021, PP 65-77, ISSN 2707-8027

IJCAB

\subsection{The Knowledge based Theory}

The firm's Knowledge-based view (KBV) is an organizational learning management concept providing strategies to organizations to achieve competitive advantage. Involving employees in operational goals administration and formulation and transforming the firms' long-term objectives helps achieve this. Factors like technical advancements, frequent deregulations and competitive conditions that are ever changing in the market necessitate knowledge within a firm to be continuously transfers and acquired. According to Cavalcanti (2003), > 55\% of the worlds GDP is produced by workers in the current world knowledge. By using and integrating knowledge more than the physical assets e.g. materials and land has accomplished shifting to service from manufacturing. In the developed world particularly, a change in structure in the productive archetype is taking place. According to Helfat and Peteraf (2003), theorists believe that the firm's resource-based view is evolving to the knowledge-based view since resources with a competitive advantage that is much sustained are immobile, inimitable and most valuable, knowledge is considered. Ariely (2003) says that the notional connection with RBV is created by a resource with the understanding of knowledge. In organizational learning, KBV is a crucial approach forming the basis of involving human capital in the firm's routine and structural activities. Its proposition is that to achieve sustainable knowledge-based competitive advantage, establishing heterogeneous knowledge structures across the firm's management hierarchies is a primary condition as the knowledge-based assets have characteristics of difficulty of social complexities, imitation and transmission.

The theory draws much reference and encouragement from management classical theories like $\mathrm{RBV}$, organizational theory and theory of the firm. The KBV assumptions are believed to have originated from RBV. It assumes that in the firm, most strategic significance is held by knowledgebased resources, application of knowledge is involved in processes and activities of production and individuals have the responsibility to chare, hold and create knowledge and that for firm existence is as result of market incapability in coordinating specialized knowledge with the role of coordinating in the frim played by the management, knowledge-based assets have characteristics of difficulty of social complexities, imitation and transmission and that the appreciative value of knowledge lead to strategic significance as compared to production factors that are traditional since they depreciate. This theory suggests in creating value, individuals use the capacity-to-act in 2 main directions: by internally and externally converting and transferring knowledge to the firm. The theory has relevance to the study as it addresses the aspect of employee involvement, which is one of the specific objectives of the study.

\subsection{Quality Improvement Theory}

According to Deming (1986), the organizational responsibility is placed entirely at the top management's door. According to Hill (1995), the systems responsibility is on the management and $80 \%$ of the firms' problems are from the system. For quality management system success, management must be committed and that investment in developing long-term relationships, selecting suppliers, creating corporate culture and processes is done by the management (Deming, 1986). In solving problems Deming (1986) had faith in a systematic approach hence promoting a universal concept of improving quality, Plan Do Check Act cycle aiming at improving performance constantly hence reducing Business organizations performance and customer requirements difference (Goetsch \& Davis, 2006). Anderson et al. (1994) posit that the theory's nature was the focus on concerns in creating organizational systems fostering learning and 
International Journal of Business Management, Entrepreneurship and Innovation, Volume 3, Issue 1, 2021, PP 65-77, ISSN 2707-8027

\section{[IJCAB}

cooperation to facilitate process management practices implementation leading to performance. In changing systems and processes top management should take the lead responsibilities (Oakland, 2004). To ensure quality management success, leadership plays an important role since creating and communicating the firm's vision of moving towards improved performance is the top management's responsibility.

For most quality problems, top management is responsible; Employees should be given clear direction on what is deemed as work that is acceptable and be provided with ways of achieving it (Kamanda, 2010). According to Deming (1986), the management should have a commitment to apply System of Profound Knowledge (SOPK) practices and principles in which an organization can reduce costs simultaneously by increase worker satisfaction, customer loyalty, quality, ultimately, profitability by reducing litigation, staff attrition, rework and waste. The theory is of relevance to this study as it gives support to performance as the study dependent variable. Performance can be realized by organizations through training employees and improving continuously hence enhancing services and product quality.

\section{Conceptual Framework}

The conceptual framework of the research has been created basing on the goals of the investigation, outcome, and predictor factors. Figure 1 shows the illustration.

\section{Independent Variables}

\section{Top management commitment}

- Areas of participation

- Operations Competency

- Top managers' participation

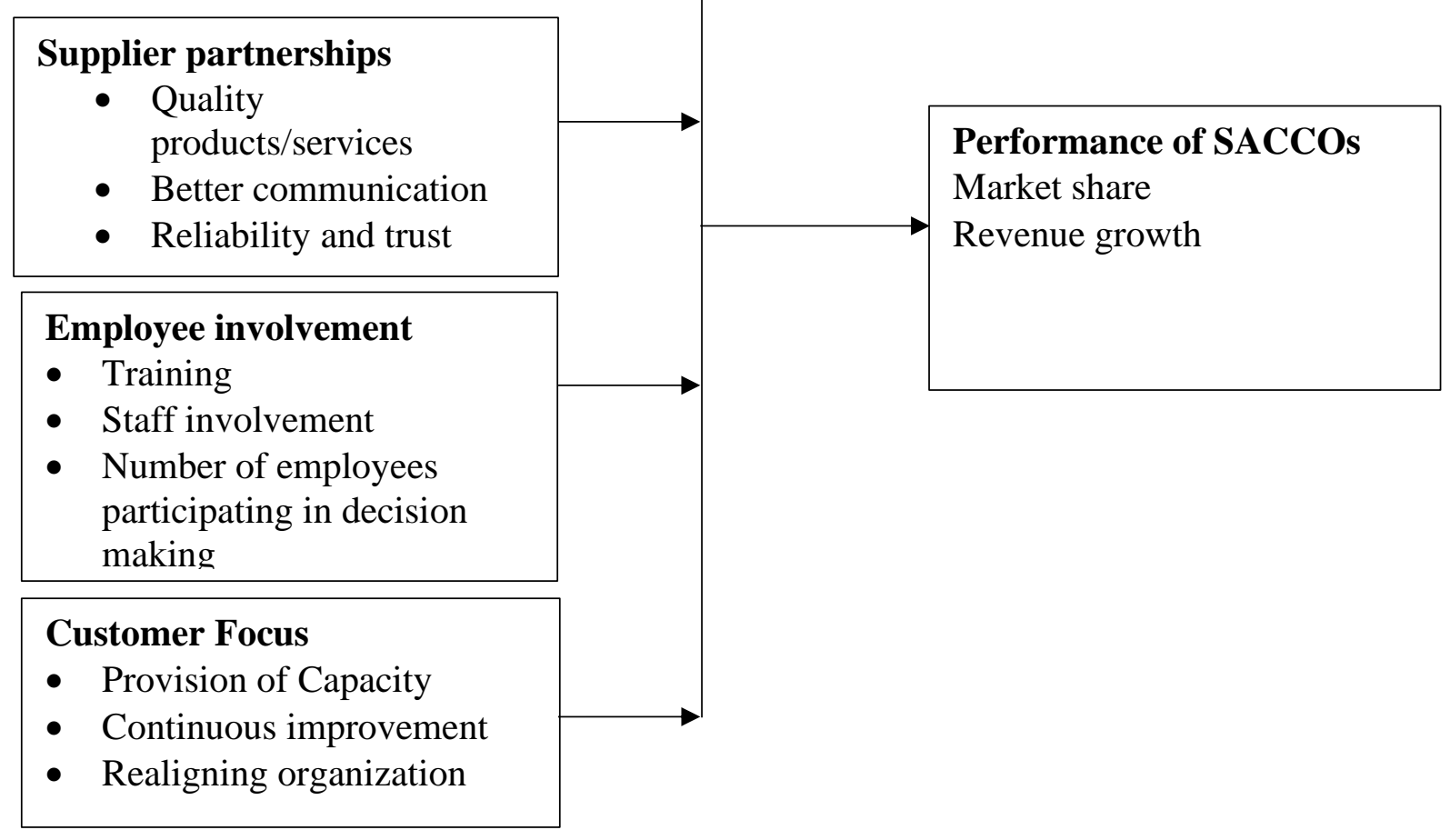

Figure 1: Conceptual Framework 
International Journal of Business Management, Entrepreneurship and Innovation, Volume 3, Issue 1, 2021, PP 65-77, ISSN 2707-8027

\section{IIJCAB}

Source: Field data (2020)

\section{Research Methodology}

A descriptive research design was preferred in explaining effectively how deposit taking SACCOs performance was affected by TQM practices. All the 13-deposit taking SACCOs in Kenya were considered the target population. 104 respondents were targeted in number and the included of all the 4 executive board of directors members, the all credit managers, Operations managers, Branch managers and the CEOs of each of the thirteen deposit taking Saccos. A census approach was used in identifying and subjecting all the County's operational and registered Saccos. Primary data collection was by questionnaires. A multiple regression was used to establish how Mombasa County deposit taking SACCOs relate with TQM practices. The study adopted the following functional specification and regression model to determine the relationship between the variables (Kutner, Nachtsheim and Neter, 2004).

\section{Data Analysis Results}

Statistics allowing entire population generalizations are presented here. Key aspects involved are regression and correlation analysis.

\subsection{Pearson Correlation Analysis}

Pearson correlation was applied to determine the relationship between performance of SACCOs and TQM practices (customer focus, employee involvement, supplier partnership and commitment of top management). Table 1 indicate the findings.

Table 1: Correlation Analysis

\begin{tabular}{|c|c|c|c|c|c|c|}
\hline & & Performance & $\begin{array}{l}\text { Top } \\
\text { management } \\
\text { commitment }\end{array}$ & $\begin{array}{l}\text { Supplier } \\
\text { partnership }\end{array}$ & $\begin{array}{l}\text { Employee } \\
\text { involvement }\end{array}$ & $\begin{array}{l}\text { Customer } \\
\text { focus }\end{array}$ \\
\hline Performance & & $\overline{1}$ & $.360^{* *}$ & $.307^{* *}$ & $.245^{*}$ & .059 \\
\hline $\begin{array}{l}\text { Top management } \\
\text { commitment }\end{array}$ &.$\stackrel{0}{0}$ & $.360^{* *}$ & 1 & .180 & .054 & .095 \\
\hline $\begin{array}{l}\text { Supplier } \\
\text { partnership }\end{array}$ & ن் & $.307^{* *}$ & .180 & 1 & .003 & .057 \\
\hline $\begin{array}{l}\text { Employee } \\
\text { involvement }\end{array}$ & 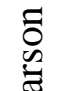 & $.245^{*}$ & .054 & .003 & 1 & .015 \\
\hline Customer focus & ص & .059 & .095 & .057 & .015 & 1 \\
\hline
\end{tabular}

**. Correlation is significant at the 0.01 level (2-tailed).

*. Correlation is significant at the 0.05 level (2-tailed).

Source: Field data (2020)

From the above table, the results suggest a strong positive correlation between top management commitment and performance as shown by correlation coefficient of 0.360 . This is an indication that effective top management commitment will lead in improving the performance of SACCOs. Supplier partnership and performance had a correlation coefficient of 0.307 therefore denoting a positive relationship. This is an indication that supplier partnership support positively contributes to performance of deposit taking SACCOs. Similarly, employee involvement and performance posted a correlation coefficient of 0.245 therefore providing a positive relationship between the variables. As such, for the performance of SACCOs to succeed, the employees must provide 
International Journal of Business Management, Entrepreneurship and Innovation, Volume 3, Issue 1, 2021, PP 65-77, ISSN 2707-8027

\section{IIJCAB}

appropriate decisions aimed at providing effective monitoring. On the same note, customer focus and performance correlated at 0.059 . This therefore is a significant relationship since appropriate customer focus policies can enhance the performance of SACCOs.

\subsection{Regression Analysis}

The researcher conducted a multiple linear regression analysis to determine the relationship between customer focus, employee involvement, supplier partnership and commitment of top management and how the affect performance of SACCOs as presented in Table 2 below.

Table 2 Regression model summary

\begin{tabular}{|l|l|l|l|l|}
\hline Model & R & R Square & Adjusted R Square & Std. Error of the Estimate \\
\hline 1 & $.886^{\mathrm{a}}$ & .785 & .598 & .39355 \\
\hline
\end{tabular}

a. Predictors: (Constant), customer focus, employee involvement, supplier partnership and commitment of top management

Source: Field data (2020)

The Determination Coefficient is at 0.785 implying that a variation of $78.5 \%$ in the SACCOs' performance is explained by independent variables' variability i.e. customer focus, employee involvement, supplier partnership and commitment of top management. As such, other factors not in the model explain only $21.5 \%$ of the variation in the performance. Thus based on Seber \& Lee (2012and Draper, Smith and Pownell (1966), it is conclusive that of the useful performance predictors at least one of the TQM practices being studied.

In testing regression model significance pertaining to difference in independent and dependent and variables means, ANOVA. The findings were as shown in Table 3.

Table 3: ANOVA

\begin{tabular}{|ll|l|l|l|l|l|}
\hline Model & & Sum of Squares & df & Mean Square & F & Sig. \\
\hline \multirow{4}{*}{1} & Regression & 3.822 & 4 & .956 & 6.169 & $.012^{\mathrm{b}}$ \\
& Residual & 12.390 & 44 & .155 & & \\
& Total & 16.213 & 48 & & & \\
\hline
\end{tabular}

a. Dependent Variable: Performance

b. Predictors: (Constant), customer focus, employee involvement, supplier partnership and commitment of top management

Source: Field data (2020)

ANOVA used in establishing regression model significance and established a less than $0.05 \mathrm{p}$ fsignificance value providing evidence demonstrating that the regression line slope was not 0 since $0.012 \mathrm{P}$ value is $<5 \%$. Thus concluding that of the independent variables; top management commitment, supplier partnership, employee involvement and customer focus was a crucial performance predictor.

Table 4 shows the Regression Model Coefficients. 
International Journal of Business Management, Entrepreneurship and Innovation, Volume 3, Issue 1, 2021, PP 65-77, ISSN 2707-8027

\section{IIJCAB}

Table 4: Regression Model Coefficients

\begin{tabular}{|l|l|l|l|l|l|}
\hline Model & \multicolumn{2}{|l|}{$\begin{array}{l}\text { Unstandardized } \\
\text { Coefficients }\end{array}$} & $\begin{array}{l}\text { Standardized } \\
\text { Coefficients }\end{array}$ & T & \multirow{2}{*}{ Sig. } \\
\cline { 3 - 6 } & $\mathrm{B}$ & Std. Error & Beta & & \\
\hline 1(Constant) & 1.090 & .587 & & 1.857 & .026 \\
Top management commitment & .249 & .085 & .176 & 1.765 & .014 \\
Supplier partnership & .230 & .077 & .301 & 3.009 & .012 \\
Employee involvement & .150 & .084 & .038 & .392 & .004 \\
Customer focus & .033 & .091 & .268 & 2.726 & .002 \\
\hline
\end{tabular}

a. Dependent Variable: Performance of SACCOs

Source: Field data (2020)

Since the $\mathrm{P}$ values are all $<0.05$, all the independent variables regression coefficients i.e. customer focus, employee involvement, supplier partnership and commitment of top management are statistically different from 0 . Since the p-value of top management 0.014 which is $>0.05$ significance level, commitment coefficient (0.249) is significantly different from 0 . Meaning a 0.249 unit increment in Saccos' performance is achieved by a unit increment in top management commitment. The e research was in agreement with Mwaniki and Bichanga (2014) who indicated that financial performance and top management commitment and related positively. Since the supplier partnership p-value (0.012) is less than 0.05 significance level, the coefficient for (0.230) is statistically significant. Meaning that a 0.230 Saccos' performance unit increment can be achieved by a unit increment in Supplier partnership would result to. The results agree with Kinai \& Were (2017) who found out that there exists an effective supplier collaboration on the organizational performance. The p-value of Employee involvement $(0.004)$ is $<0.05$ significance level so its coefficient $(0.150)$ is statistically significant and this means that 0.150 unit increment in the Sacco's performance can be as a result of a unit increment in Employee involvement. This agrees with a past study done by Karia (2011) who found out that employees were more satisfied when involved in organizational decision making which in turn contributed to the organization's performance.

The p-value of Customer focus (0.002) is < 0.05 significance level, so its coefficient $(0.033)$ is statistically significant implying that 0.033-unit increment in Saccos performance can be as a result of a unit increment in Customer focus. This is in agreement with Keinan \& Karugu (2018) who posit that customer focus and operational performance Organizations had a positive and significant relation. It was concluded that in SACCOs performance, all the TQM practices independent variables positively impact it and are crucial predictors. Saccos performance and TQM practices regression model was as below: Performance $=1.090+0.249$ (Top management commitment $)+$ 0.230 (Supplier partnership) +0.150 (Employee involvement) +0.033 (Customer focus). $\mathrm{Y}=1.090$ $+0.249 \mathrm{X}_{1}+0.230 \mathrm{X}_{2}+0.150 \mathrm{X}_{3}+0.033 \mathrm{X}_{4}$ regression equation was established from $\mathrm{Y}=\alpha+\beta 1 \mathrm{X} 1$ $+\beta 2 \mathrm{X} 2+\beta 3 \mathrm{X} 3+\mathrm{X} 4+\varepsilon$. It indicates that holding all factors (customer focus, employee involvement, supplier partnership and commitment of top management) constant, factors influencing performance of SACCOs was 1.090. It was also evident that with all the independent variables at 0, a 0.249 Saccos performance score increment can be achieved with a unit increment in top management commitment led. A unit increment in supplier partnership led to a 0.230 increase in performance of SACCOs. On the other hand, a unit increase in employee involvement led to a 0.150 increase in the scores of performances of SACCOs; and a unit increase in customer 
International Journal of Business Management, Entrepreneurship and Innovation, Volume 3, Issue 1, 2021, PP 65-77, ISSN 2707-8027

\section{IIJCAB}

focus led to a 0.033 increase in performance of SACCOs. This infers that top management commitment influences the increase of performance of SACCOs most followed by supplier partnership, employee involvement and then customer focus.

\section{Conclusion}

From the inferential statistics it was concluded that Top management commitment, Supplier partnerships, Employee involvement and customer focus were key to influencing the performance of the deposit taking SACCOs. The implementation of total quality management practices had forced the Saccos to focus on customers by doing regular market survey so as to align their processes with the ever-dynamic customer requirement, needs and expectation. They focus on getting regular feedback and act on customer complains immediately thus giving them a competitive edge over their competitors. They also use critical incident technique to identify issues that delight or dissatisfy their customers. Going by the regression analysis results, the study concluded that top management commitment greatly influences the performance of Saccos. Based on the inferential analysis results, the study concluded that there exists a positive relationship between supplier partnership and performance. It also concluded that supplier partnership support positively contributes to performance. On Customer focus, the study concluded that there is a considerable level of application of customer focus in the Saccos. The study found out that customer focus and performance were positively related hence the conclusion that customer focus policies can enhance the performance of SACCOs. Finally, the study indicated that most SACCOs involved their employees in their day to day business decision making hence resulting to high level of participation which on the other hand influenced the performance of the SACCOs. The finding therefore inferred that there is high level of ethics and integrity among employees, employees are committed to quality improvement and are educated and trained towards quality improvement.

\section{Recommendations}

Because individual SACCOs performance wide disparities were established by the study, it recommends that Organizations should invest in implementation of TQM practices that would help to improve their performance. Going by the conclusion made concerning the top management commitment and involvement, the study recommends that at all levels in their institution, appropriate continuous programs allowing quality improvement should be developed by organizations. It was further recommended that the organization's management establish a robust Supplier Relationship management system to help them in growing, monitoring and treating its suppliers like long-term partners as they are integral part of the organizations business. This will promote and facilitate communication and thereby improving the value creating processes efficiency and effectiveness. The study further recommends that more trainings be conducted amongst the employees as there were noted cases where some employees were not aware of some aspects of TQM practices in the surveyed organizations. Such training would go a long way in eliminating the existing information asymmetry. The study revealed that Customer Focus had an influence on performance thus recommending that customers be focused by the institutions and make sure they meet their needs, staff members' staff involvement in the process is important and ensuring customer complaints are solved since in institutions, they are the failure or success factors and management to make sure achievement of quality. 
International Journal of Business Management, Entrepreneurship and Innovation, Volume 3, Issue 1, 2021, PP 65-77, ISSN 2707-8027

\section{IIJCAB}

\section{REFERENCES}

Agus, A., Suhaimi Ahmad, \& Jaafar, M. (2009). An Empirical Investigation on the Impact of Quality Management on Productivity and Profitability: Associations and Mediating Effect. Contemporary Management Research, 5(1), 77-92.

Andrle, J. (2009). Total quality management in public transportation. Research Result Digest, 3,

Barney, J. B. (1991). Firm resources and sustained competitive advantage. Journal of Management, 17, 99-120.

Barney, J. B. (1996). The resource-based theory of the firm. Organization Science, 7(5), 469.

Biggar, J. L. (2010). Total quality management in construction. Transactions of the American Association of Cost Engineers, Q.1.1-Q.1.4.

Burati, J. L., Mathews, F. M., \&Kalidindi, S. N. (2012). Quality management organisations and techniques. J. Construction Engineering and Management, Vol.118, No. 1, pp 112-118.

Cooper, D. R. \& Schindler, P. S. (2006). Business research methods. New York: McGraw-Hill.

Cooper, M. \&Ellram, L. (2013). Characteristics of supply chain management and the implications for purchasing and logistics strategy. The International Journal of Logistics Management, 4(2), 13-24.

Davies, W. (2010). 'Understanding Strategy'. Strategy \& Leadership, vol. 28, no. 5, pp. 25- 30.

Demirbag, M., Tatoglu, E., Tekinkus M. \& Zaim, S. (2010). An Analysis of the Relationship between TQM Implementation and Organizational Performance: Evidence from Turkish SMEs. Journal of Manufacturing Technology Management, 17, (6), 829-847.

Fulop\& Lilley. (2004). The impact of quality management practices on performance and competitive advantage. Decision Sciences, 26(5), pp. 659- 691.

Garvin, D. A. (2004). Competing on the eight dimensions of quality. Harvard Business Review, pp.101-9.

Harrington, H. J., Reid, J. \&Carr, R. (1999). "What's this "systems” stuff, anyhow?" The TQM Magazine, Vol 11 Issue: 1

International Organization for Standardization [ISO] (2008 - 2015). International Organization for Standardization

Irsova, Z. \& Havranek, T. (2010). Measuring Bank Efficiency: A Met - Regression Analysis. Prague Economic Papers, (4), 307 - 328.

Karani, S. R. \&Bichanga, W. O. (2012). Effects of Total Quality Management Implementation on Business Performance in Service Institutions: A Case of Kenya Wildlife Services. International Journal of Research Studies in Management

Karia A. (2011). "Total quality management: the need for an employee centered, coherent approach", The TQJ Magazine, pp.92-106.

Kathaara C. (2014). TQM Practices and Operational Performance of Commercial Banks in Kenya. International Journal of Social Sciences and Entrepreneurship, 1 (9), 288-314.33.

Kaynak. (2012). The effects of total quality management practices on employees' work related attitudes. The TQM Magazine, pp.30-43

Kumar, M. R. (2011). Total quality management as the basis for organizational transformation of Indian Railways: a study in action research. DBA thesis, Southern Cross University.

May, G. W. M. (2016). Total Quality Management Critical Success Factors And Non-Financial Performance Of Deposit Taking SACCOs In Nairobi, Kenya. Unpublished Project. University of Nairobi

McElyea, B. E. (2003). 'Organizational change models', Futurics, vol. 27 
International Journal of Business Management, Entrepreneurship and Innovation, Volume 3, Issue 1, 2021, PP 65-77, ISSN 2707-8027

\section{IJ JCAB}

Munizu, M. (2013). The impact of total quality management practices towards competitive advantage and organizational performance: Case of fishery industry in South Sulawesi province of Indonesia. Pakistan Journal of Commerce Social Sciences, 7(1)

Mwaniki, C.and Okibo, B. W. (2014). Effects of Total Quality Management on Financial Performance in the Banking Sector: a Case Study of National Bank of Kenya. IOSR Journal of Economics and Finance (IOSR-JEF), e-ISSN, 2321-5933.

Ngware, M. W. (2011). Total Quality Management in secondary schools in Kenya. Quality Assurance in Education, 14(4), 339-362.

Njanja, W. L. \&Pelissier, R. (2010). 'An Investigation into the Effect of Management Factors on Performance of Micro, Small and Medium Enterprises in Kenya.' International Journal of Business and Management, Vol.5, No.11; November 2010.

Njenga, E. W. \& Kidombo, H. (2017). Influence of implementation of quality management system on operational performance of technical training institutions in Meru County: A case of Nkabune Technical Training Institute, Kenya

Oakland, J. (2012). Total Quality Management. Oxford: Heinemann

Oakland, J. S. (2003). TQM: text with cases. 3rd ed. Oxford: Butterworth Heinemann.

Oakland, J. S., (2010). 'Total Quality Management: The Route to Improving Performance', 2edn, Oxford, Butterworth Heinemann Ltd.

Oluwatoyin, A., \&Oluseun, A. (2009). Total quality management, a test of the effect of TQM on performance and stakeholder satisfaction. Unpublished MBA thesis, Blekinge Institute of Technology.

Prajogo, D.I., \&Sohal, A.S. (2013). The Relationship between TQM Practices, Quality Performance, and Innovation Performance: an Empirical Examination. International Journal of Quality and Reliability Management, 20(8), 901-918.

Reed, R., Lemak, D. J. \& Mero (2000). Total Quality Management and sustainable competitive advantage. Journal of Quality Management, vol. 5

Reed, R., Lemak, D. J. \& Mero (2002). When Quality Works: A Premature Post Mortem on TQM. Journal of Business and Management, vol. 6, no. 4

Sadikoglu, E. \&Zehir, C. (2010). "Investigating the effect of innovation and employee Performance on relationship between TQM practices and firm performance.” An empirical study of Turkish firms. International Journal of Production Economics, pp 1-14.

SASRA (2013). The Sacco Supervision Annual Report: Deposit Taking Saccos. Nairobi, Kenya.

SASRA (2015). The Sacco Supervision Annual Report: Operations and Performance of Deposit Taking Saccos Societies in Kenya.

Schwartz, S. J. (2005). A new identity for identity research: Recommendations for expanding and refocusing the identity literature. Journal of Adolescent Research, 20

Sharma, B., \&Gadenne, D. (2012). An inter-industry comparison of quality management practices and performance. Managing Service Quality: An International Journal, 12(6), 394-404.

Shekoufeh, N. \&Siavash, E. (2013). A study of the Impact of TQM on Organizational Performance of the Telecommunication Industry in Iran. European Online Journal of Natural and Social Sciences, 2013.

Silverman, D. (2010). Qualitative research. Sage Publishers.

Talib, F., Rahman, Z. \& Qureshi, M. N. (2012). "Total quality management in service sector: a literature review". International Journal of Business Innovation and Research, Vol. 6, No.3, pp. 259-301 
International Journal of Business Management, Entrepreneurship and Innovation, Volume 3, Issue 1, 2021, PP 65-77, ISSN 2707-8027

IIJCAB

Tippins, M. J., \&Sohi, R. S. (2003). IT Competency and Firm Performance: IS Organizational Learning a Missing Link?, Strategic Management Journal, (24), 2003:745-761.

Whiting, L. S. (2008). Semi-structured interviews: guidance for novice researchers. Nursing Standard, 22(23), 35.

This is an open-access article published and distributed under the terms and conditions of the (c) (i) \&

Creative Commons Attribution 4.0 International License of United States unless otherwise stated. Access, citation and distribution of this article is allowed with full recognition of the authors and the source. Authors seeking to publish with an Internationally Peer Reviewed Journals should consider https://www.ijcab.org/ by writing to the Editor at editor@ijcab.org or submitting online at https://journals.ijcab.org/journals/index.php. The articles must be quality and meet originality test.

$\frac{I J C A B}{\text { Publishing Group }}$ 